\title{
Analysis of Underwater Topographic Survey of Stilling Basin Based on Unmanned Survey System
}

\author{
Hui Xie, ${ }^{1}$ Haoran Wang $\mathbb{D}^{1,2}$ Yayi Yang, ${ }^{3}$ Yongcan Chen, ${ }^{2,4}$ Jun Yang, ${ }^{5}$ Shuang Wang, \\ and Zhaowei Liu ${ }^{2}$ \\ ${ }^{1}$ Sichuan Energy Internet Research Institute, Tsinghua University, Chengdu 610042, China \\ ${ }^{2}$ State Key Laboratory of Hydroscience and Engineering, Tsinghua University, Beijing 100084, China \\ ${ }^{3}$ Sichuan Technology and Business College, Dujiangyan 611830, China \\ ${ }^{4}$ Southwest University of Science and Technology, Mianyang 621010, China \\ ${ }^{5}$ Sichuan Electic Power Design \& Consulting Co., Ltd., Chengdu 610041, China \\ Correspondence should be addressed to Haoran Wang; hrwang@mail.tsinghua.edu.cn
}

Received 27 January 2021; Revised 4 March 2021; Accepted 17 March 2021; Published 2 April 2021

Academic Editor: Yubo Jiao

Copyright (C 2021 Hui Xie et al. This is an open access article distributed under the Creative Commons Attribution License, which permits unrestricted use, distribution, and reproduction in any medium, provided the original work is properly cited.

\begin{abstract}
The combination of Global Positioning System-Real Time Kinematic (GPS-RTK) and depth sounder is an important technical method of modern underwater topographic survey. In this paper, the combined technology was integrated with unmanned surface vehicle (USV) technology to construct an unmanned survey system suitable for underwater topographic survey in stilling basin, and it was applied to survey the underwater topography of the stilling basin of Tingzikou hydrojunction project. Based on the surveying and mapping data and 3D model, the trend of elevation change of the stilling basin including apron, end sill, antiscour section, and river convergence section was analyzed. The results show that, for the surface outlet stilling basin of Tingzikou, after flood, the structure is complete, the boundaries are clear, the water quality is good, and there is little sediment on the surface of apron from overflow dam section to end sill. Furthermore, no obvious sediment or structural abnormality has been found in the still basin. Affected by the bedrock and cofferdam cobble gravel sediment, the elevation of the antiscour section and the downstream convergence section of the surface outlet stilling basin increased significantly. For the bottom outlet stilling basin of Tingzikou, there is large sediment within a range of $20 \mathrm{~m} \sim 40 \mathrm{~m}$ from the bottom sill and the maximum height of it reaches $2.04 \mathrm{~m}$, while there is no obvious sediment or structural abnormality in the remaining region of basin. The critical sedimentation height can effectively judge the safety grade of the sedimentation height in stilling basin and provide a reliable support for assessing the overall safety of stilling basin. The application of unmanned survey technology improves the accuracy and timeliness of underwater topography and sedimentation distribution of stilling basin, which has significant application research value and promotion significance.
\end{abstract}

\section{Introduction}

As an important energy dissipating facility of hydraulic structure, the safe operation and long-term stability are essential to ensure the power generation and flood discharge of a hydropower station [1-3]. Hyperconcentrated flow, gravels and boulders flowing through the dam into the basin with high-speed flow, and riverbed sandstones flowing into the basin with turbulent flow after the end sill can cause scour damage to the apron and side wall of stilling basin with the certain extent, and it will increase the risk of cavitation damage [4-7]. Therefore, the underwater topographic survey and underwater sedimentation detection of the stilling basin during the operation period are important parts of the routine inspection work for hydraulic structure and are the key to timely grasp the risk and hidden dangers of energy dissipation and to evaluate the safety status of the water discharge stricter of the power station. For the surveying and mapping of the stilling basin, the traditional manual measurement has large workload and low efficiency, and the 
implementation of multibeam measurement on the ship is difficult and costly, and both conventional methods need to be measured by the mother ship [8-11] which affect the effectiveness of underwater topographic survey in the stilling basin to a certain extent. Li et al. [12] provided a visual detection method and applied to stilling basin; however, it is necessary for the underwater robot dive to the bottom of the water for detection, which is inefficient.

With the development of information, automation control, and surveying and mapping technology, underwater survey is more and more integrated, refined, and standardized. The combination of GPS-RTK and depth sounder is an important technical method of modern underwater topographic survey. The combined technology was integrated with USV technology to construct an unmanned survey system which can greatly reduce the labor intensity and improve the automation degree and work efficiency of survey. Additionally, it also has the advantages that the traditional survey methods cannot match such as flexibility, rapidity, and applicability [13-15]. In the past five years, unmanned intelligent technology has been adopted in various fields, such as reservoir topographic survey and storage capacity calculation [16-20], bathymetric and underwater topographic surveying and mapping of oceans, rivers, and lakes [21-23], and monitoring and control of water environment pollution [24-26], etc. with remarkable results.

In the analysis and postprocessing stage of survey results, some scholars have done researches on the formation mechanism of sediment in stilling basin. Wang et al. [27], Athat et al. [28], and Zhao et al. [29] used FLUENT to solve the hydraulic factors in the node area and solved the suspended sediment equation and riverbed deformation equation by the water-sand noncoupling method and explored the sediment distribution of suspended load. Madej et al. [30], Wang et al. [31], and Zhang et al. [32] systematically studied the sediment deposition characteristics under different roughness conditions through experimental methods, and found that the sediment was mainly deposited at the boundary between the main flow and the backflow area with a vector velocity of less than $0.1 \mathrm{~m} / \mathrm{s}$. Song et al. [33] established the calculation formula of flow resistance and water depth change caused by sediment movement by theoretical analysis method. Gao and Abrahams [34] used dimensionless analysis to get the formula for calculating resistance caused by bed load movement. The numerical simulation method and experimental method have fully explained the deposition phenomenon in the backflow area, and the theoretical calculation formula can be used to analyze the sedimentation principle in special situation. However, the research on the classification of sedimentation height has not been found, and it is impossible to use the sedimentation height to evaluate the overall safety of the stilling basin.

In conclusion, although the application of intelligent undammed survey technology is active, few surveying and mapping practices for draining building such as stilling basin have been found, and unmanned survey systems, process or postprocessing methods for the structure of stilling basin, and the characteristics of regularized measuring areas have not yet been established. The occurrence of sediment in the backflow area has reached consensus in the field of hydraulics, but there is little research on the degree of sediment to determine the safety grade of the stilling basin. This paper has constructed an unmanned underwater topographic survey system based on GPS-RTK combined with depth sounder and has applied it to engineering practice to realize the autonomous underwater surveying and mapping of stilling basin. In this paper, the degree of sediment in stilling basin has been safely classified to provide support for evaluating the overall safety of stilling basin. This research is an application innovation of frontier surveying and mapping technology effectively applied in the field of water conservancy and hydropower engineering. It meets the requirements for hydropower development and puts forward new requirements for digital watersheds, digital hydropower, and "Internet+" smart hydropower stations. It has significant application research value and promotion significance.

\section{Project Background}

The Tingzikou hydrojunction project (Tingzikou) is one of the six key projects for the improvement of the Yangtze River flood control system. It is the only controlling backbone project of Jialing River mainstream. The main functions of Tingzikou are flood discharge, irrigation, and urban and rural water supply and power generation, considering navigation, and sand blocking and sediment reducing. The drainage structure of the Tingzikou consists of eight surface outlets and five bottom outlets, which adopt the form of underflow dissipation. The main task of the surface outlets is flood discharge, and the exit adopts a wide tail design. The surface outlet stilling basin is a tetragonal structure surrounded by the middle guide wall, the right guide wall, the surface sill, and the apron. The top elevation of apron is $355.0 \mathrm{~m}$, the basin length is $135 \mathrm{~m}$, and the basin width is $143.5 \mathrm{~m}$. The end sill of the stilling basin is continuous, and the elevation of the sill is $367 \mathrm{~m}$. The length of the antiscour section of the end sill is $35 \mathrm{~m}$ and the elevation is $360.3 \mathrm{~m}$. The main tasks of the bottom outlet are flood discharge and sand discharge, and it also serves as a diversion bottom outlet during construction. The bottom outlet stilling basin is a rectangular structure surrounded by the left guide wall, the middle guide wall, the end sill, and the apron. The top elevation of apron is $354.0 \mathrm{~m}$, the basin length is $187.7 \mathrm{~m}$, and the basin width is $75 \mathrm{~m}$. The end sill of the stilling basin is continuous, and the elevation of the sill is $367 \mathrm{~m}$. The antiscour section of the end sill is $35 \mathrm{~m}$ in length and $360.3 \mathrm{~m}$ in elevation [35-37]. The plan and the picture of surface outlet stilling basin and bottom outlet stilling basin are shown in Figure 1 and Figure 2, respectively.

With the transition of Tingzikou from capital construction period to production and operation period, the importance of safe and stable operation of the project is increasingly apparent. The peak-volume of Jialing River is relatively large. The design flood peak of Tingzikou is $34500 \mathrm{~m}^{3} / \mathrm{s}$. and the design flood recurrence interval of the energy dissipation is 100 years. In July 2018, Sichuan 


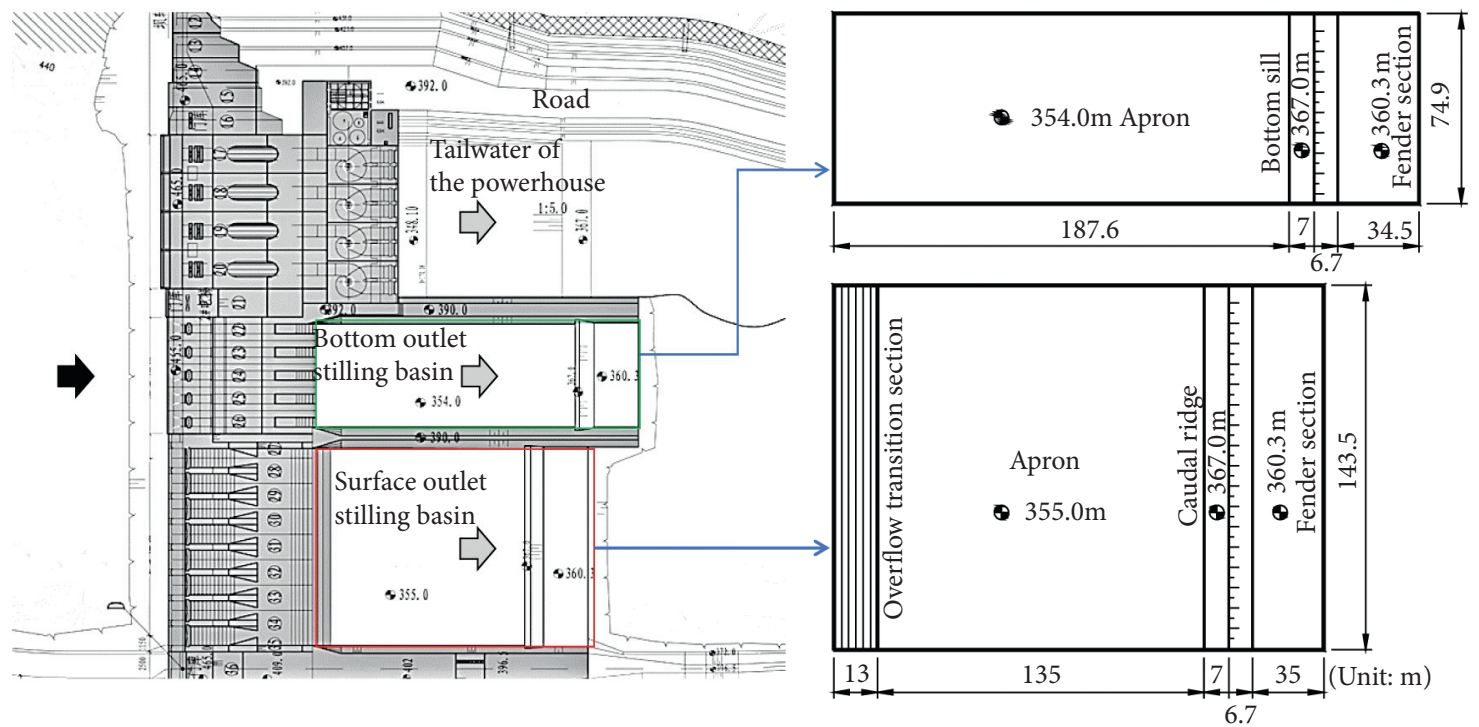

Figure 1: The plan of surface outlet stilling basin and bottom outlet stilling basin.

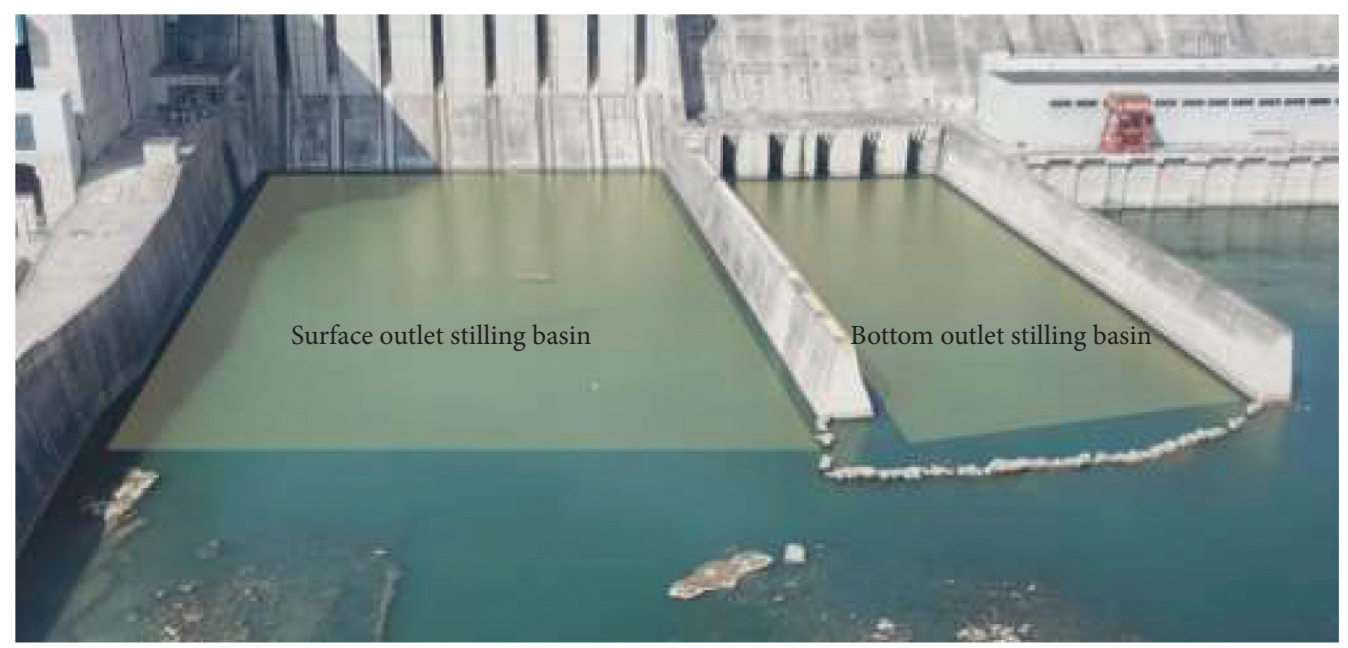

FIgURE 2: The picture of surface outlet stilling basin and bottom outlet stilling basin.

experienced severe grievances. The peak discharge of the Tingzikou reached $25130 \mathrm{~m}^{3} / \mathrm{s}$, which is the largest one in the last 80 years. It refreshed the largest measured flood since the historical record. After flood season, to patrol and evaluate the underwater structure of stilling basin to determine structural integrity and potential structural risks were urgently needed. The underwater topography and sedimentation measurement of stilling basin can timely reflect the overall shape of the apron and preliminarily obtain the distribution of rubble and sediment deposition and provide guidance for the underwater positioning refinement measurement. In view of the urgent need for underwater sedimentation measurement in the Tingzikou, and the limitations of the existing surveying methods, the intelligent USV system carrying single beam bathymetry is adopted in the research, which can replace the manual measurement without drainage. Through this method, the bottom sedimentation distribution data and monitoring data on the high precision positions are collected. This research method can support the further structural safety assessment and normal operation of the stilling basin.

\section{Principle of Unmanned Survey System}

3.1. Unmanned Survey System. Underwater topographic survey includes two parts: positioning and water depth measurement [38]. The unmanned survey system for the underwater topography of the stilling basin, formed by GPSRTK combined with depth sounder, is a real-time dynamic positioning survey system. It adopted RTK (real-time kinematic) real-time difference method on orientation, and echo sounding technology on water depth survey. This system consists of four parts, base station, mobile station, communication system, and control site (ground site). Figure 3 shows the schematic diagram of the unmanned survey system for the underwater topography of the stilling basin. 


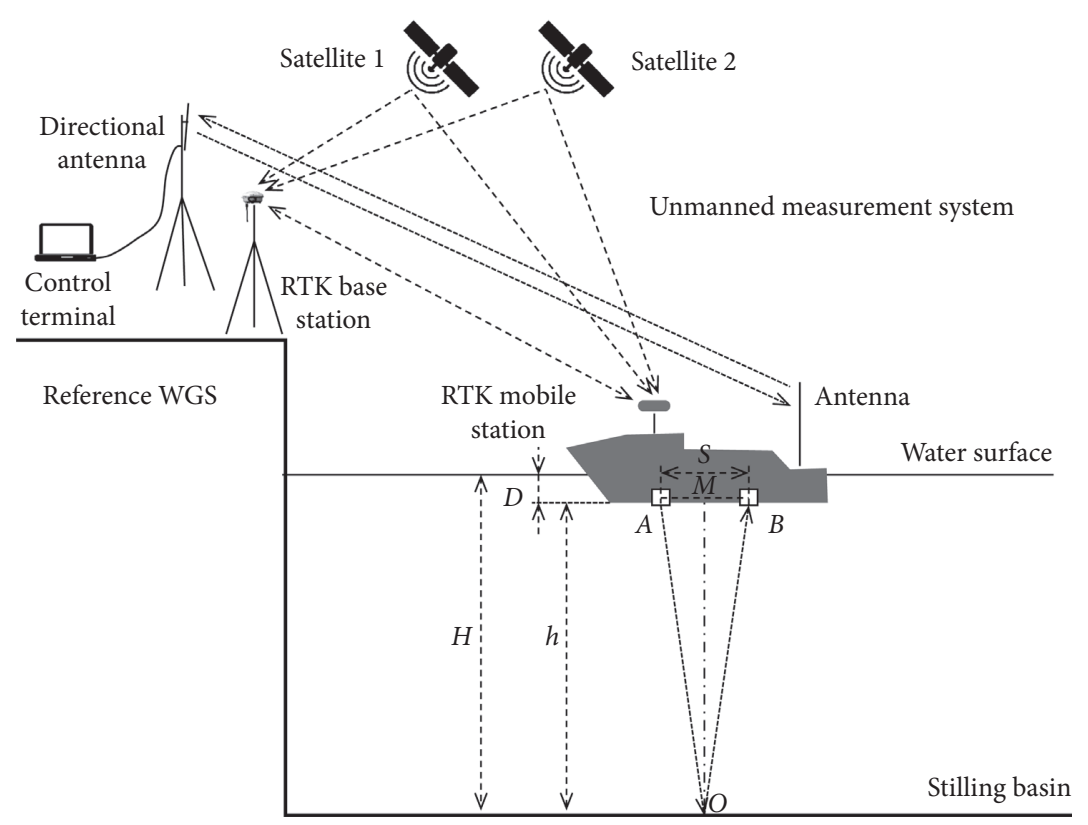

FIGURE 3: The diagram of unmanned survey system for underwater topography of the stilling basin.

The core function of base station is to determine the geodetic coordinate system. The base station consists of GPS receiver and antenna, and the independent base station including transmitting station and antenna $[16,39]$, and it needs to be placed in the higher-lying open area near the side wall of stilling basin, to enhance the effect of the communication module and avoid the multipath effect caused by occlusion. The mobile station system uses the base station as the origin coordinate to solve the relative position coordinates of each measuring point. The mobile station includes four parts, the USV module (including hull, electronic compass, propulsion system, energy power system, obstacle avoidance radar, wireless transmission system, and shipborne master control), mobile GPS receiver and antenna, differential antenna, and depth sounder. The detailed parameters of iBoat BS2 USV and senor are shown in Table 1. In addition, the control terminal is an important ground control system. It realizes remote communication, image transmission, and command feedback with the USV and sounding software through the image transmission and communication equipment. The USV and RTK are shown in Figures 4 and 5, respectively.

3.2. Principle of Depth Sounder. The single beam bathymetry technology gets the overall data through the water depth survey and data recording of the various discrete monitoring points, and it is widely used in the underwater topographic survey of the river and lake reservoirs because of its simple operation and high cost performance. HD-510 USVmounted single beam bathymetry is used as the depth sounder of this system. Its working principle is to use the transducer to emit sound waves in the water. The sound waves are reflected and recovered when they touch the obstacles such as apron and sediment. According to the time interval of echo and launch pulse time combined with the wave velocity in the surveyed water, the distance between the bottom of water and the bottom of boat is calculated, that is, the depth of the measuring point [39]. As can be seen from Figure 3, the water depth should be

$$
\begin{aligned}
H & =D+h, \\
h & =\mathrm{MO}=\sqrt{(\mathrm{AO})^{2}-(\mathrm{AM})^{2}}, \\
& =\sqrt{\left(\frac{c t}{2}\right)^{2}-\left(\frac{S}{2}\right)^{2}},
\end{aligned}
$$

where $H$ is the measured water depth, $D$ is the draft depth, unit, $m, h$ is the transducer to the bottom depth, $c$ is the propagation speed of the sound wave in the water, $S$ is the transducer spacing, and $t$ is the time intervals.

For the transceiver transducer, equation (2) can be simplified as

$$
h=\frac{c t}{2}
$$

In the echo sounding principle, the propagation speed of ultrasonic waves in water is approximately $1500 \mathrm{~m} / \mathrm{s}$. The propagation speed of ultrasonic waves in water is affected by the changes of temperature, salinity, hydrostatic pressure, etc.; among them, temperature has the greatest influence. Therefore, the parameter compensation is performed in HiMAX software.

3.3. Process of Underwater Topographic Survey. The standardized underwater survey process of stilling basin is the key to ensure the measurement results. In view of the structural characteristics and surveying and mapping requirements of stilling basin, the research process is as follows: 
TABLE 1: The main parameters of USV and depth sounder.

\begin{tabular}{lccc}
\hline USV & Technical parameters & Depth sounder & Technical parameters \\
\hline Hull weight & $14.00 \mathrm{~kg}$ & Working frequency & $200 \mathrm{kHz}$ \\
Size & $1.05 \mathrm{~m} \times 0.56 \mathrm{~m} \times 0.27 \mathrm{~m}$ & Sound speed adjustment range & $1370 \sim 1700 \mathrm{~m} / \mathrm{s}$ \\
Wind and wave resistance level & Level 3 wind and level 2 wave & Precision & $\pm 10 \mathrm{~mm}$ \\
Endurance & $4 \mathrm{~h}$ & Resolution & $0.01 \mathrm{~m}$ \\
Maximum speed & $4.5 \mathrm{~m} / \mathrm{s}$ & Transducer open angle & $5 \pm 0.5^{\circ}$ \\
Waterproof level & $\mathrm{IP} 65$ & Draught adjustment & $0 \sim 15 \mathrm{~m}$ \\
Remote control distance & $2 \mathrm{~km}$ & Weight & $0.50 \mathrm{~kg}$ \\
Draught & $0.2 \mathrm{~m}$ & Waterproof level & IP 66 \\
Software & HiMAX & Power supply & $12 \mathrm{~V} \mathrm{DC}$ \\
\hline
\end{tabular}

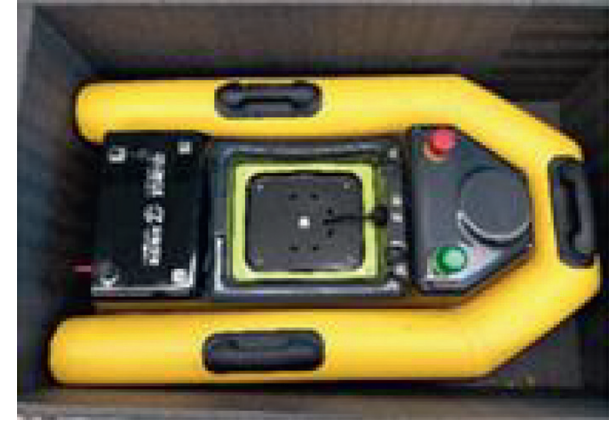

Figure 4: The unmanned surface vehicle (USV).

(1) To select the appropriate launch point after comprehensively examining the terrain around the survey area.

(2) To turn on the directional antenna and configure the RTK base station, connect the antenna to the PC, turn on the remote control, turn on the USV power supply, and test the communication to check if it is normal.

(3) To turn on the visual serial port, and test the antenna to receive the USV data normally.

(4) To plan the route in the satellite map area to be measured, and load generated route point files, to ensure the software is connected. In this research, a total of 44 routes parallel to the guide wall were planned along the discharge direction of the surface outlet stilling basin, with a single route of about $230 \mathrm{~m}$ and a row spacing of $3 \mathrm{~m}$. On a single route, measurements were taken every $0.2 \mathrm{~m}$ apart. A total of 27 routes parallel to the guide wall are planned for the bottom outlet stilling basin, and a single outlet is about $260 \mathrm{~m}$ with a row spacing of $4 \mathrm{~m}$. On a single route, a measurement was collected every $0.2 \mathrm{~m}$, as shown in Figure 6.

(5) To turn on the sounder software, connect GPS set as fixed solution or RTK solution, collocate geographic coordinates, meridian, receive data packet format, serial communication format, and connect the serial port to ensure normal communication.

(6) To set the antenna height of USV mobile station, draught, local underwater sound speed, and measure the depth by distance. The data recording will be

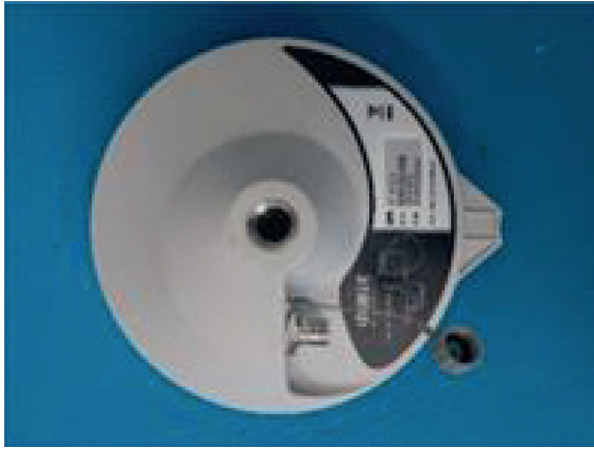

FIgure 5: The real-time kinematic (RTK).

synchronous with the sounding survey start. The automatic route survey starts when clicking the automatic navigation control of USV control software.

(7) To take over the USV manually when all the routes are completed, stop sounding recording, save the collected data, and take the USV back.

When using USV for underwater topographic surveying, the time synchronization between the systems and the attitude control of the hull should be ensured as much as possible to reduce the time error and measurement error [8]. Through the system coordination control, time synchronization processing, and measurement point control, to ensure the time synchronization between the GPS and depth sounder. According to the variation of water level in stilling basin, the measured data of initial hull attitude instability are selected to reduce the measurement error. The field working is shown in Figures 7 and 8.

\section{Results and Analysis of the Survey}

4.1. Results of Underwater Topographic Survey of the Stilling Basin. The data processing after the survey of stilling basin is completed, and the sounding data is filtered, sampled, previewed, and exported by the sounder software. The surface outlet stilling basin survey operation totaled 2.5 hours, and a total of 54202 sets of effective measurement data were generated. And the bottom outlet stilling basin survey operation totaled 1.5 hours, and a total of 10925 sets of effective measurement data were generated. The coordinates of the collected data are WGS84 geodetic coordinates 


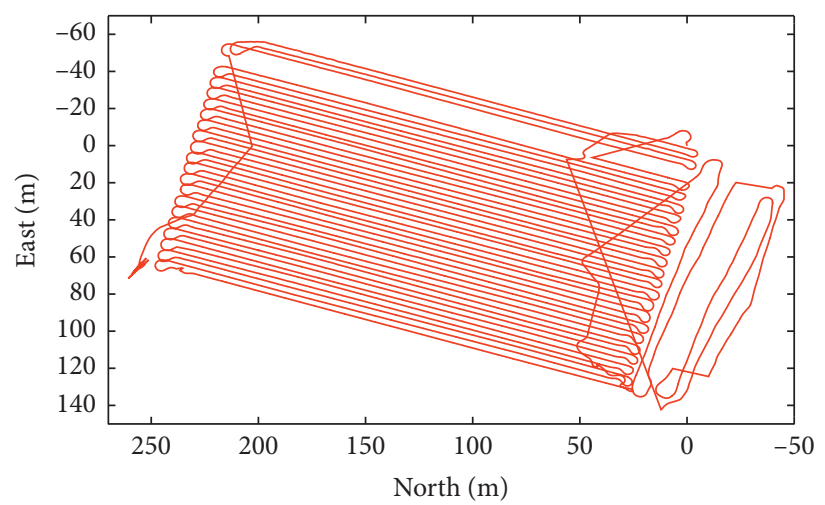

(a)

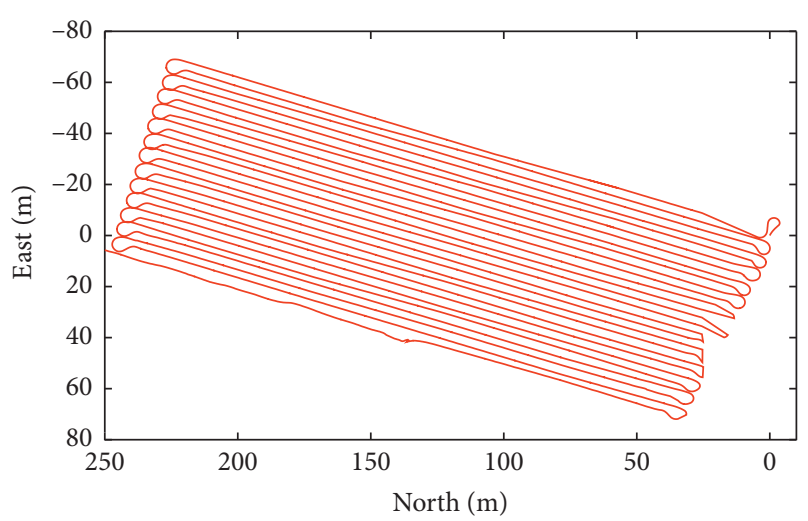

(b)

FIgURE 6: The path planning of USV. (a) Surface outlet stilling basin. (b) Bottom outlet stilling basin.

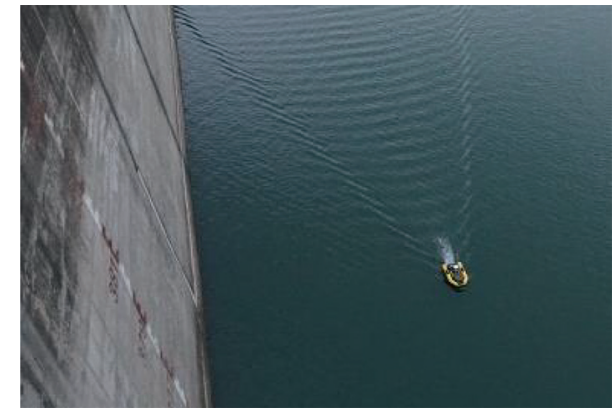

FIGURE 7: The field working picture of USV.

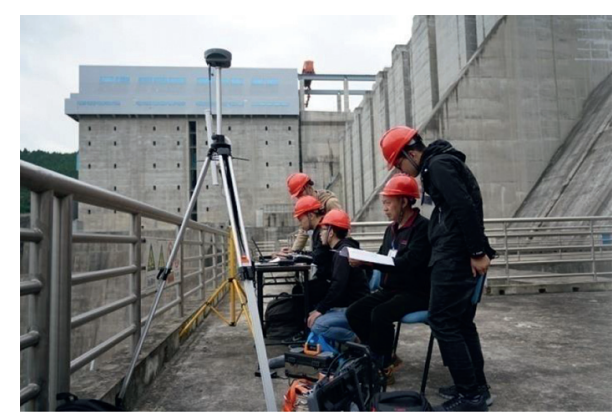

Figure 8: The field working picture of surveyors.

system, in which the north coordinate, east coordinate, underwater elevation, measured water depth, and surface elevation data are used for later MATLAB data processing. Under the influence of the peaking power generation tail water in the day, the water depth of the surface outlet stilling basin is decreasing. The maximum water level variation intervals are $0.5 \mathrm{~m}$. The water depth in the bottom outlet stilling basin shows an upward trend, and the maximum water level fluctuation range is about $0.6 \mathrm{~m}$. Some data anomalies are caused by the hull tilting or near the side wall of the stilling basin. The water depth time series data collected by the ship-borne depth sounder is well coupled with the $0.5 \mathrm{~h}$ interval water depth measurement data provided by the power station management department, indicating that the sounder is well calibrated and the measurement process is standardized and effective. The surface outlet stilling basin and bottom outlet stilling basin water level elevation process is shown in Figure 9.

The bottom elevation data of the stilling basin is filled and rendered according to different colors, and finally the underwater topographic data of the reservoir area is obtained. Figure 10 shows the contour distribution of the surface outlet and bottom outlet of the stilling basin. From Figure 10(a), in the regular rectangular area between the inflow surface and the end tail of surface outlet stilling basin, the depth of water is deeper than other areas; the underwater height is the lowest; and the end tail is clearly visible. In the figure, we can see it is the highest on underwater height in the whole survey area. After the end tail, the underwater topography is complex; the siltation is obvious. The sediment presents a trend of increasing gradually towards the downstream river. It can be seen from Figure 10(b) that the water depth in the apron zone between bottom outlet stilling basin and end sill is deep, and the change in underwater elevation is clearly visible. There is a large sediment in the range of $20 \sim 40 \mathrm{~m}$ from the drop-step. There is no obvious change in elevation between the sediment and the end sill, and the end sill is clearly visible. After the end sill, like the surface outlet stilling basin, the underwater topography distribution is complicated, and the sedimentation is obvious. The sediment gradually increases to the downstream channel.

4.2. Analysis of the Results. In order to quantitatively analyze the underwater siltation distribution and topographic change of the stilling basin, the transition section between overflow dam and the apron is used as the initial characteristic section, and seven characteristic sections are selected along the discharge direction of stilling basin for the comparison of relative elevations. The measured values of each characteristic section of surface outlet stilling basin are shown in Table 2. Similarly, starting from the drop-step of the bottom outlet stilling basin, 12 characteristic sections are selected along the discharge direction of stilling basin for the 


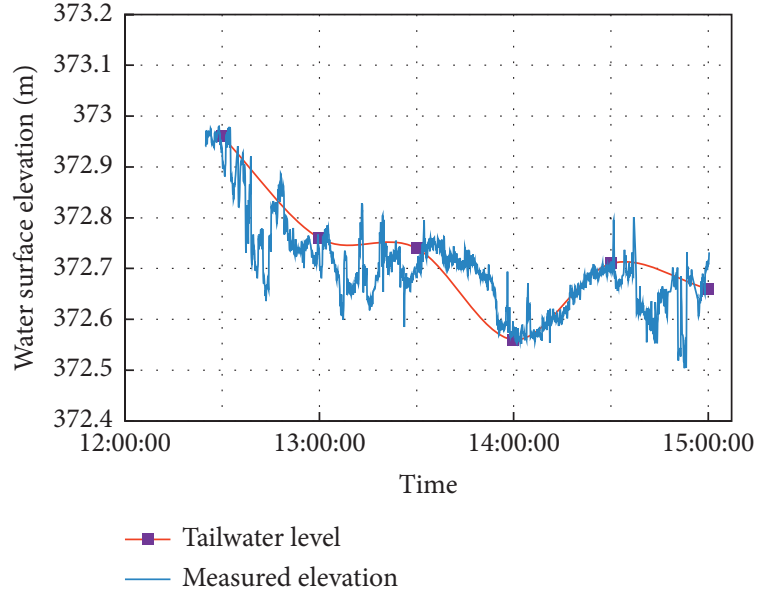

(a)

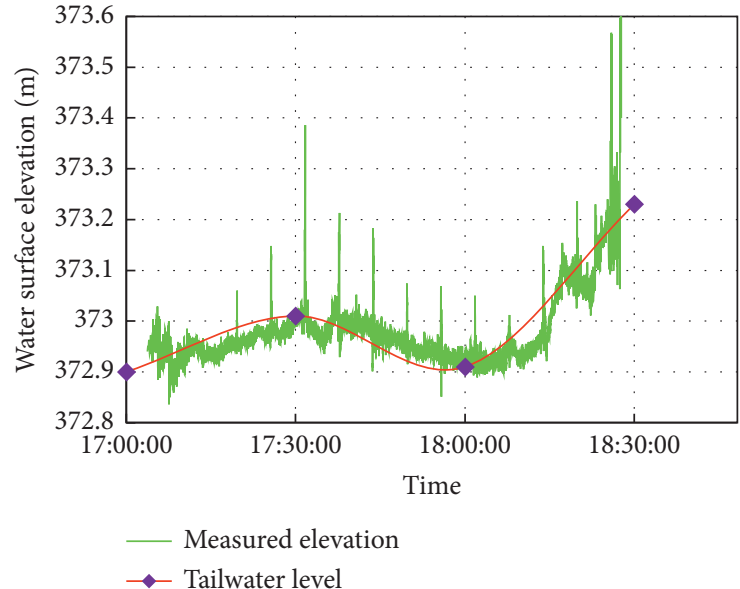

(b)

FIgUre 9: Diagram of water surface elevation variation. (a) Surface outlet stilling basin. (b) Bottom outlet stilling basin.

comparison of relative elevations. The measured values of each characteristic section of bottom outlet stilling basin are shown in Table 3. The sedimentation height should be

$$
h_{s}=H-h_{r} \text {, }
$$

where $h_{s}$ is the sedimentation height, $H$ is the measured height, and $h_{s}$ is reference value.

The data of Table 2 shows that the average elevation of section 1 (the transition section) is higher than that of the apron sections, and the difference between the average elevation of apron and the reference value can be used to characterize the average sediment thickness of apron. The water in surface outlet basin is clear, and there is no large sediment such as gravels. The stilling basin apron is characterized by small siltation and high homogeneity. The average elevation and elevation standard deviation increase with the direction of discharge from section 2 to section 4 . At the left hand of apron the underwater sediment of about $30 \mathrm{~m}$ strip width can be seen clearly, and the sediment is much more than the other areas of apron. The structure of end sill is complete and the boundaries of the upstream apron and the downstream antiscour section are clear. There is a little sediment at the top of the end sill, and the average sediment thickness of section 5 is only $0.04 \mathrm{~m}$. The average sedimentation height of the $35 \mathrm{~m}$ long antiscour section after the end sill is $0.38 \mathrm{~m}$ and the homogeneity is high. Due to the influence of bedrock and gravel sediments, the underwater elevation of the antiscour section and the downstream river convergence section is significantly increased and the closer it is to the downstream, the higher the underwater elevation is. The average elevation can be up to $364.03 \mathrm{~m}$, and the standard deviation is $3.11 \mathrm{~m}$.

The data in Table 3 shows that the average elevation of the stilling basin apron in section 1 immediately adjacent to the drop-step is only $0.09 \mathrm{~m}$ higher than the reference elevation, and there is a little sediment in section 1 . The sediment in section 2 , section 3 , and section 4 is obvious, the maximum sedimentation height can reach $2.04 \mathrm{~m}$, and the sediment is mainly distributed in the range of $20 \mathrm{~m} \sim 40 \mathrm{~m}$ after drop-step. There is a little difference between the average elevations of section 5 section 8 and the reference elevation. Within this range, the stilling basin apron as a whole has the characteristics of small sedimentation and high homogeneity. The structure of the end sill is complete, the boundaries of the upstream apron and the downstream antiscour section are clear, the siltation at the top of the end sill is less, and the average sediment thickness of the section 9 is only $0.02 \mathrm{~m}$. Due to the influence of bedrock and gravel sediment, the underwater elevation of the antiscour section and the downstream river convergence section is significantly increased and the closer it is to the downstream, the higher the underwater elevation is.

From the data in Table 2, the section elevation comparison chart of surface outlet stilling basin is shown in Figure 11. It can be found that the difference in elevation in section 1 is not significant, while the difference in elevation between section 2 and section 4 gradually increased that the thickness of sedimentation in apron is increasing along the flow direction. Section 6 is the antiscour section behind the apron. There is a little difference in elevation of this section and the standard deviation of elevation is $0.4 \mathrm{~m}$. It is significantly affected by the flow velocity and riverbed cobbles after the antiscour section and the elevation difference is particularly obvious. The maximum height difference of the section is $7.82 \mathrm{~m}$ and the standard deviation is $3.11 \mathrm{~m}$.

From the data in Table 3, the section elevation comparison chart of the bottom outlet stilling basin is shown in Figure 12. It can be found that the difference in elevation of section 1 in the bottom outlet stilling basin is not significant, and the difference in elevation among section 2 section 4 is obvious, indicating that there is an obvious sediment in stilling basin apron. The sediment is distributed within the range of $20 \mathrm{~m} \sim 40 \mathrm{~m}$ from the drop-step and it gradually decreases along the direction of flow. Within section $5 \sim$ section 8 , the elevation difference is not apparent and the sediment in apron is small. It is significantly affected by the flow velocity and riverbed cobbles in antiscour (section 10 and section 11) and antiscour transition (section 12) section 


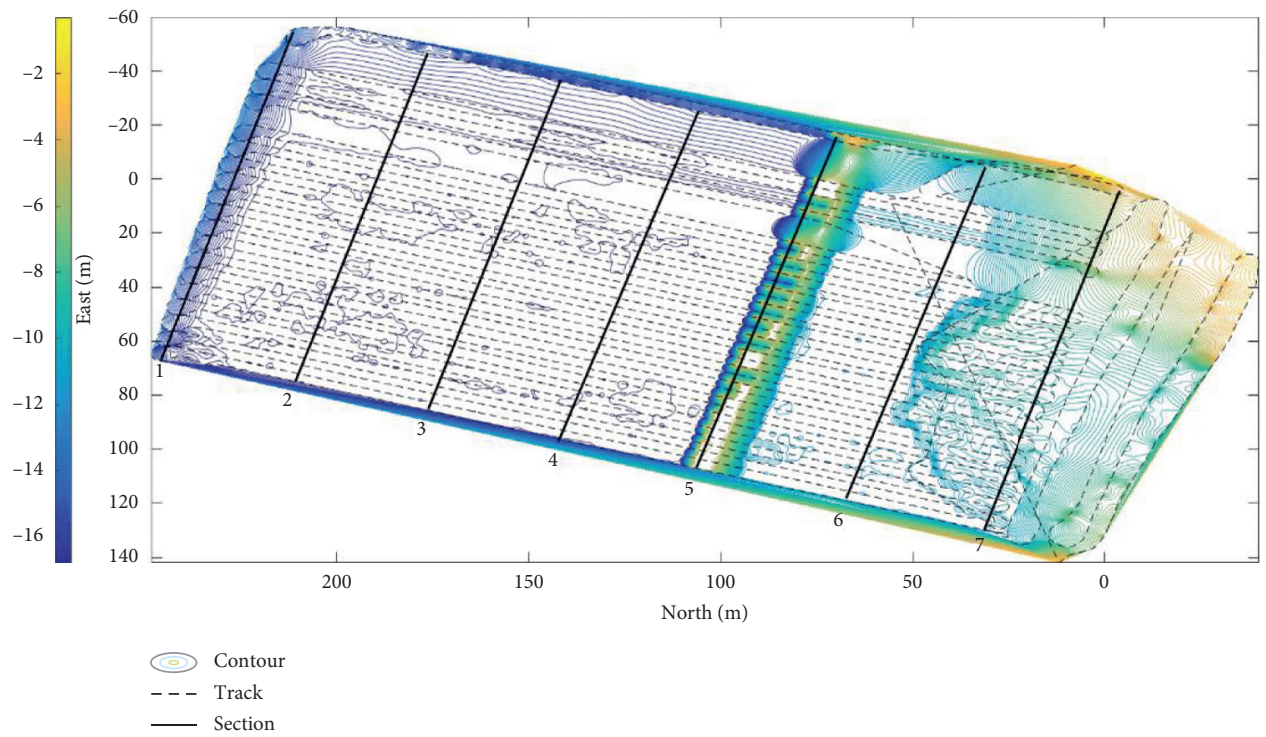

(a)

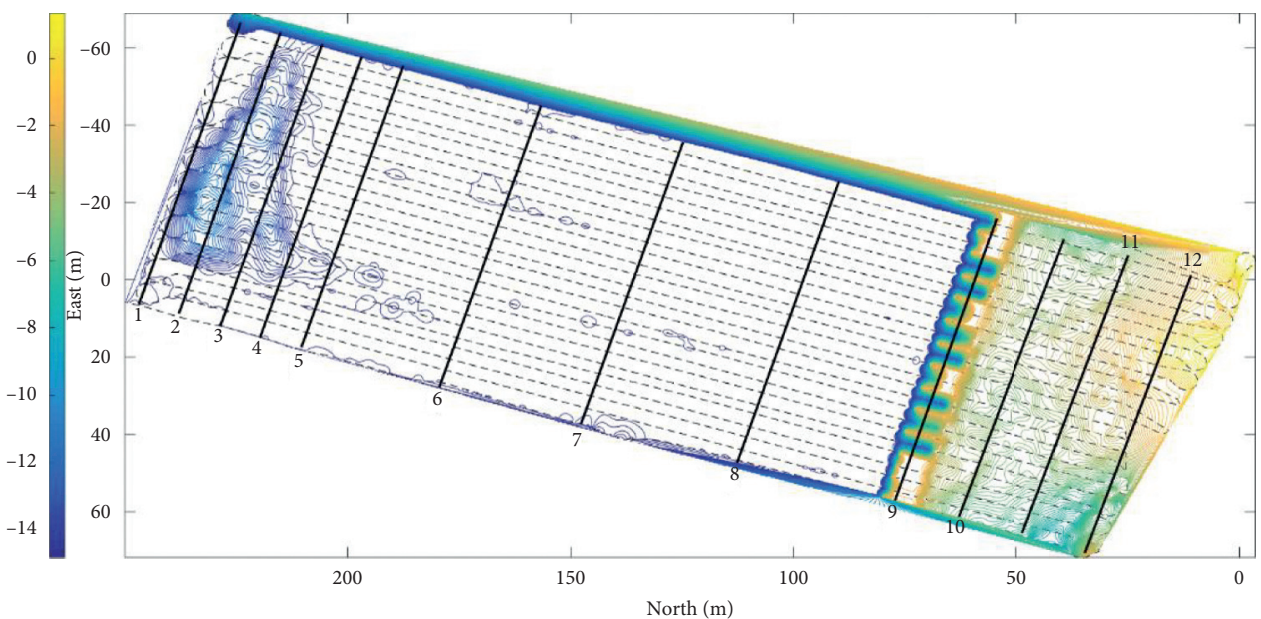

\begin{tabular}{ll}
-- & Track \\
0 & Contour \\
\hline & Section
\end{tabular}

(b)

Figure 10: Underwater topographic contour lines and selected sections of the stilling basin. (a) Surface outlet stilling basin. (b) Bottom outlet stilling basin.

TABLE 2: Comparison table of elevation parameters among selected sections of the surface outlet stilling basin (unit: $\mathrm{m}$ ).

\begin{tabular}{|c|c|c|c|c|c|c|}
\hline Section no. & Location & Maximum height & Minimum height & Average height & Standard deviation & Reference value \\
\hline 1 & Overflow transition section & 357.15 & 356.54 & 356.73 & 0.26 & - \\
\hline 2 & Apron & 355.42 & 355.23 & 355.29 & 0.08 & 355.00 \\
\hline 3 & Apron & 356.02 & 355.23 & 355.44 & 0.33 & 355.00 \\
\hline 4 & Apron & 356.59 & 355.22 & 355.54 & 0.59 & 355.00 \\
\hline 5 & End sill & 367.08 & 367.00 & 367.04 & 0.03 & 367.00 \\
\hline 6 & Antiscour section & 361.39 & 360.48 & 360.68 & 0.40 & 360.30 \\
\hline 7 & Antiscour transition section & 368.58 & 360.76 & 364.03 & 3.11 & - \\
\hline
\end{tabular}

Note. The data in the table is based on the statistical calculation of multiple corresponding measurement points on each section. 
TABLE 3: Comparison table of elevation parameters among selected sections of the bottom outlet stilling basin (unit: $\mathrm{m}$ ).

\begin{tabular}{|c|c|c|c|c|c|c|}
\hline Section no. & Location & Maximum height & Minimum height & Average height & Standard deviation & Reference value \\
\hline 1 & Apron & 354.33 & 354.12 & 354.20 & 0.09 & 354.00 \\
\hline 2 & Apron & 356.04 & 354.08 & 355.15 & 0.86 & 354.00 \\
\hline 3 & Apron & 354.88 & 354.06 & 354.45 & 0.38 & 354.00 \\
\hline 4 & Apron & 354.84 & 354.09 & 354.26 & 0.33 & 354.00 \\
\hline 5 & Apron & 354.47 & 354.09 & 354.19 & 0.16 & 354.00 \\
\hline 6 & Apron & 354.16 & 354.05 & 354.13 & 0.05 & 354.00 \\
\hline 7 & Apron & 354.20 & 354.10 & 354.14 & 0.04 & 354.00 \\
\hline 8 & Apron & 354.15 & 354.11 & 354.13 & 0.02 & 354.00 \\
\hline 9 & End sill & 366.93 & 366.89 & 366.91 & 0.02 & 367.00 \\
\hline 10 & Antiscour section & 364.59 & 363.01 & 363.80 & 0.68 & 360.30 \\
\hline 11 & Antiscour section & 365.26 & 362.19 & 364.26 & 1.23 & 360.30 \\
\hline 12 & Antiscour transition section & 367.47 & 362.72 & 365.45 & 2.06 & - \\
\hline
\end{tabular}

Note. The data in the table is based on the statistical calculation of multiple corresponding measurement points on each section.

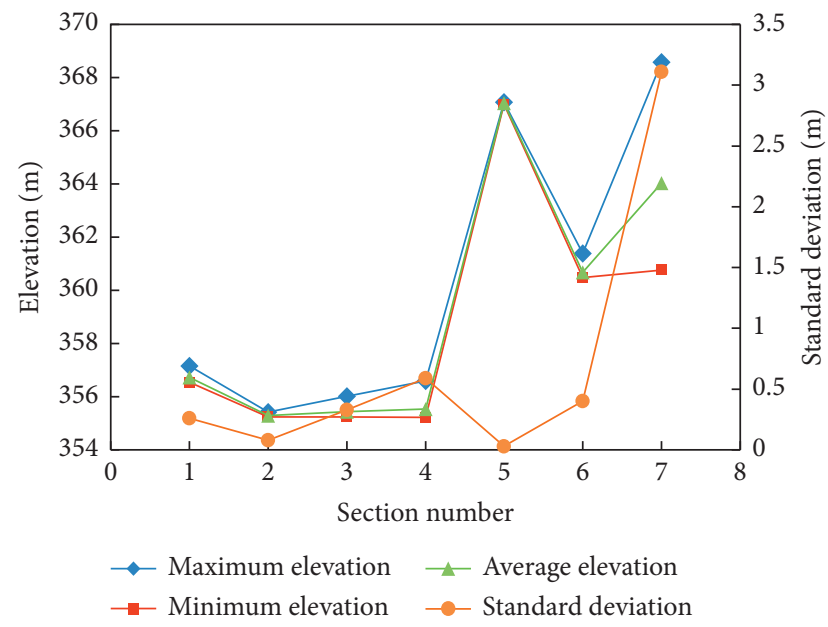

(a)

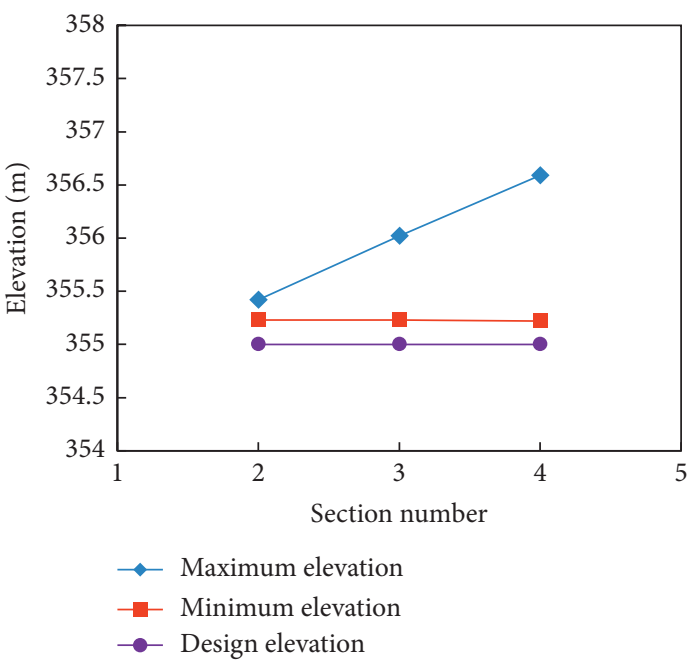

(b)

Figure 11: Comparison diagram of section elevation of the surface outlet stilling basin. (a) Diagram of section elevation and standard deviation. (b) Section elevation change of stilling basin apron.

and the elevation difference is particularly obvious. The maximum elevation difference can reach $4.96 \mathrm{~m}$, and the standard deviation is $2.06 \mathrm{~m}$.

4.3. Three-Dimensional Underwater Topography. Through the mesh and surf functions in MATLAB, the three-dimensional (3D) model of the underwater topography of stilling basin is constructed. As is shown in Figure 13, it comprehensively presents the elevation change trend of overflow dam section, apron, end sill, antiscour section, and the river convergence section. The $3 \mathrm{D}$ model can directly and vividly reflect the fluctuation in the height of the stilling basin measurement area, and make the underwater morphology and sedimentation situation clear at a glance. It can be seen that no obvious sediment or structural abnormality has been found in the basin area of surface outlet stilling basin, while the elevation difference of underwater topography between the antiscour section and the downstream convergence section is obvious. However, obvious sediment has been found near the drop-step in bottom outlet stilling basin, and no structural abnormalities have been found. Meanwhile, the elevation difference of underwater topography between the antiscour section and the downstream convergence section of bottom outlet stilling basin is obvious. The irregularity of the end sill area is caused by missing data.

\section{Discussions}

5.1. Analysis of Sediment Disciplines. According to the results of the unmanned survey system, there is no obvious sediment in the apron of surface outlet stilling basin while there is a large amount of sediment in the bottom outlet stilling basin. For the function of the surface outlet stilling basin is to release flood, almost no upstream sand stone is discharged into it, while the function of the bottom outlet stilling basin is to release flood and discharge sand and the sediment in it mainly comes from the silted sand stone in the reservoir area. The sedimentation difference between surface outlet stilling basin and bottom outlet stilling basin can be directly shown in Figure 14. 


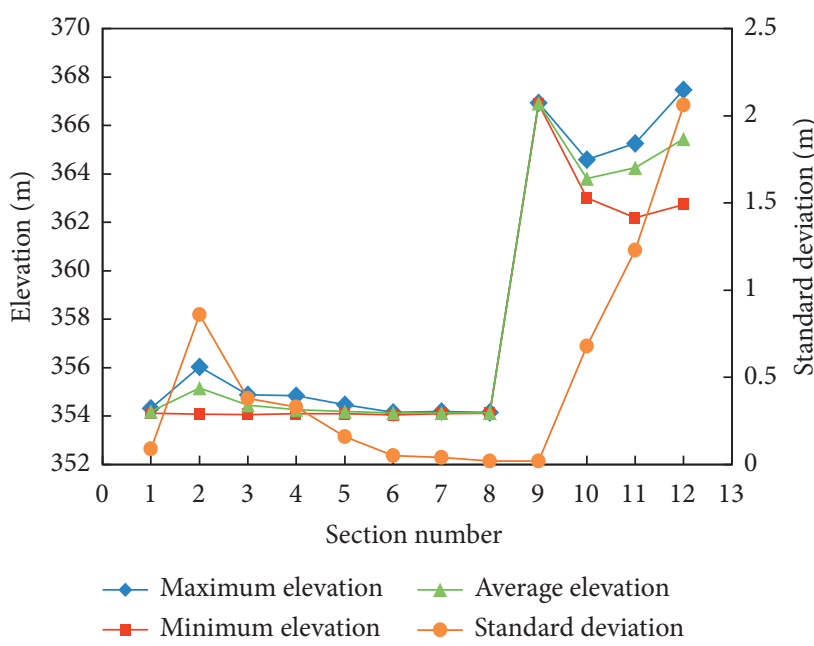

(a)

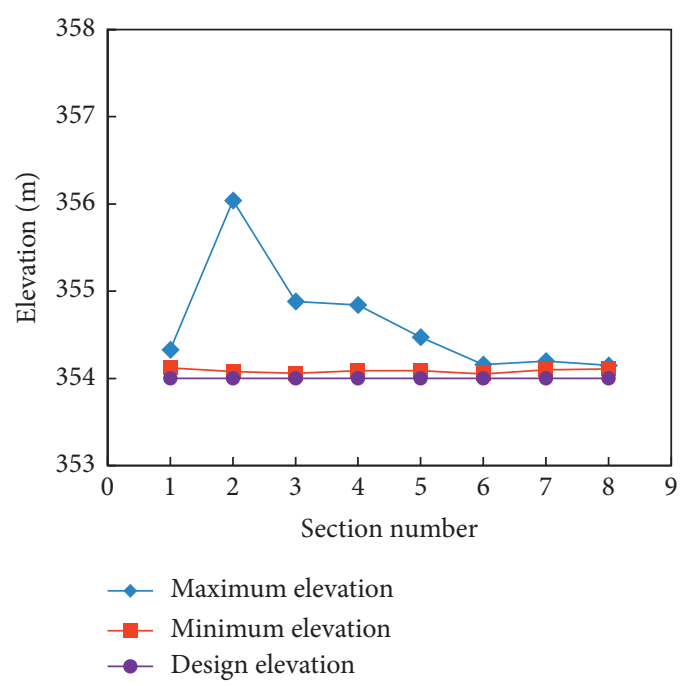

(b)

Figure 12: Comparison diagram of section elevation of the bottom outlet stilling basin. (a) Diagram of section elevation and standard deviation. (b) Section elevation change of stilling basin apron.

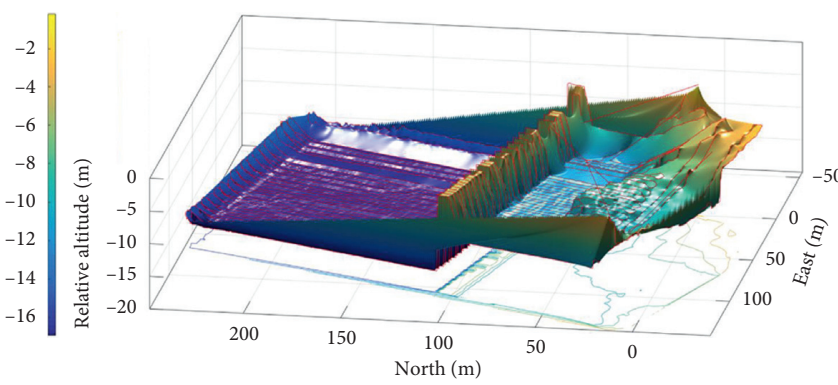

(a)

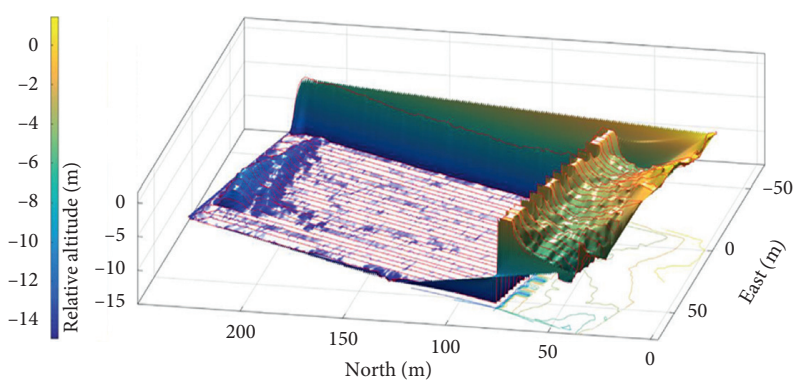

(b)

Figure 13: Three-dimensional underwater topography of stilling basin. (a) Surface outlet stilling basin. (b) Bottom outlet stilling basin.

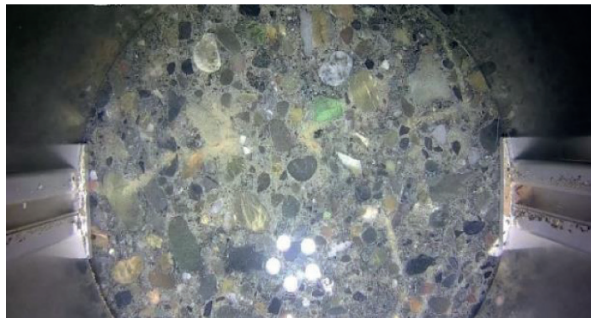

(a)

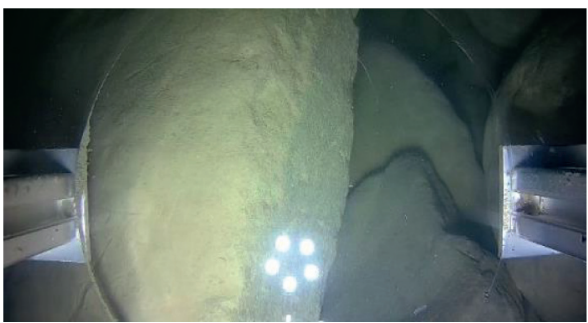

(b)

FiguRE 14: HD underwater pictures of the stilling basins. (a) Surface outlet stilling basin (no sediment). (b) Bottom outlet stilling basin (obvious sediment).

It can be seen from the results of section division that the sand stone sediment in the bottom outlet stilling basin is within a fixed range of $20 \mathrm{~m} \sim 40 \mathrm{~m}$ near the drop-step, just in the longitudinal backflow area of flood discharge, for the sand stone in the upstream reservoir area cannot be carried further downstream by the flow and it begins to sediment under the influence of gravity. Meanwhile, the main sediment is located more than $20 \mathrm{~m}$ away because the sand stone has certain velocity and inertia after being impacted by the flow.

As we know, when the sectional depth is less than the critical depth, the flow is supercritical flow, while the 
downstream is subcritical flow, and the hydraulic jump, as shown in Figure 15, is an inevitable result from supercritical flow to subcritical flow. Small water depth and high velocity are characteristics of the contraction section before the hydraulic jump. The pressure in the hydraulic jump section changes obviously with the water depth of the section, with high fluctuating pressure and violent turbulence.

In the hydraulic jump section, the velocity changes greatly, the flow morphology is complex, the velocity distribution is extremely uneven, and the flow movement intensity varies greatly, which will lead to the negative velocity vector and that is the backflow. In the bottom outlet stilling basin, the sediment is in the backflow area of hydraulic jump. It can be seen from Figure 15 that the hydraulic jump divides the flow into two areas, the surface rolling area above and the main flow area below. There is sediment in the hydraulic jump and that is in the backflow area.

The sediment concentration in water changes with the difference of velocity and depth of water, and at the same time, with the change of relevant hydraulic factors, it will cause scour and sediment. The formula of the relationship between sediment carrying capacity and velocity [40] is

$$
S=k \frac{v^{3}}{g h w}+S_{0},
$$

where $S$ is the sediment carrying capacity, $k$ is the coefficient, $v$ is the average velocity, $g$ is the acceleration of gravity, $h$ is the depth of water, $w$ is the sedimentation speed, and $S_{0}$ is the initial sediment concentration.

It can be known from the formula above that the larger the flow velocity is, the stronger the sediment carrying capacity is. Only when the velocity is low, the sand would be deposited and the sediment will appear. The backflow area can be divided into two parts: positive and negative. In these two parts, there is flow exchange and the flow velocity can be expressed as follows:

$$
U^{2}=u^{2}+v^{2}
$$

where $u$ is the lateral velocity, $v$ is the longitudinal velocity, and $U$ is the magnitude of the vector velocity. Studies have shown that sediment is mainly deposited at the junction of main flow and backflow, and usually its scalar velocity is less than $0.1 \mathrm{~m} / \mathrm{s}$ [31].

According to the formula of sedimentation rate,

$$
G_{S}=0.0235 U_{\infty} b h\left(S_{\infty}-S_{r}\right),
$$

where Gs represents the sedimentation rate, $U_{\infty}$ represents the velocity of main flow, $b$ and $h$ are geometric parameters of the section, $S_{\infty}$ is the sediment concentration of main flow, and $S r$ is the sediment concentration of backflow area.

When the suspended sediment concentration in backflow area is lower than that in mainstream area, the sedimentation rate will always be nonzero, and the sedimentation phenomenon in the backflow area will inevitably occur until there is no difference in sediment concentration between the two areas.
To sum up, the backflow area is located in the hydraulic jump section with large velocity gradient, full turbulence, and high shear stress, and as the decrease of vector velocity in backflow area is greater than the increase of turbulence intensity, the sediment carrying capacity of the flow is reduced, the sediment carrying capacity in main flow area is greater than that in backflow area, and the sedimentation rate is nonzero. The sediment begins to appear, and it will continue to deposit in the backflow area until the sedimentation rate is zero. At the same time, when the high-speed flow falls into the bottom outlet stilling basin, under the influence of drop-step, the surface of the flow forms a backflow area, and the water in backflow area meets the water in main flow area, which presents a relatively static state, so a large number of sediment stay near the drop-step.

5.2. Classification of Sedimentation Height. According to the results above, the sediment in the apron of bottom outlet stilling basin is big. With the high-speed flow of the next flood discharge, the cobbles in the bottom sediment may have a risk to cause cavitation damage to apron and side wall of stilling basin. In addition, the sediment height has a great influence on the flow pattern. As is shown is [41], the water tank test shows that as the sediment height increases, the flow pattern changes from a uniform flow to an antislope hydraulic jump, and as the sediment height decreases, the flow pattern changes from antislope hydraulic jump or a locally backflow to a uniform flow. When the sediment height is low, the water flows uniformly along the sediment in the form of supercritical flow. When the sediment height increases to a certain extent, the flow will suddenly form an antislope hydraulic jump at the upstream face of sediment, and the water level in front of the sediment increases sharply. Once the sediment in apron of the stilling basin caused the antislope hydraulic jump, the stilling basin will operate at a high water level. Moreover, the corrosion on the rest of the apron caused by cobbles may lead to cavitation damage, which is harmful to the safety of stilling basin.

In order to analyze the influence of sediment in apron of the stilling basin on flow and structural safety, and to judge the magnitude of the impact of different sedimentation heights on structure safety of stilling basin, different security levels of the stilling basin can be correspondingly classified by different heights of sediment. By introducing the research results of [41], as is shown in Figure 16, the sudden increase of water level caused by the increase of sedimentation height is the $A-B-C$ trend line; the steep decrease of water level caused by the decrease of the sedimentation height is the $C-D-A$ trend line; the height of sediment causing a sudden increase of the water level is the upper critical sedimentation height $h_{s l}$; and the height of the sediment causing a steep drop in water level is the lower critical sedimentation height $h_{s 2}$.

$$
\begin{aligned}
& h_{S 1}=h_{k}^{28 \times i_{1}-3.5 \times i_{2}+0.065 \times F_{r}+1.42}, \\
& h_{S 2}=h_{k}^{25.7 \times i_{1}-4.6 \times i_{2}+0.11 \times F_{r}+1.1},
\end{aligned}
$$

where $h_{s 1}$ is the upper critical sedimentation height, $h_{s 2}$ is the lower critical sedimentation height, $h_{k}$ is the critical depth, $i_{1}$ 


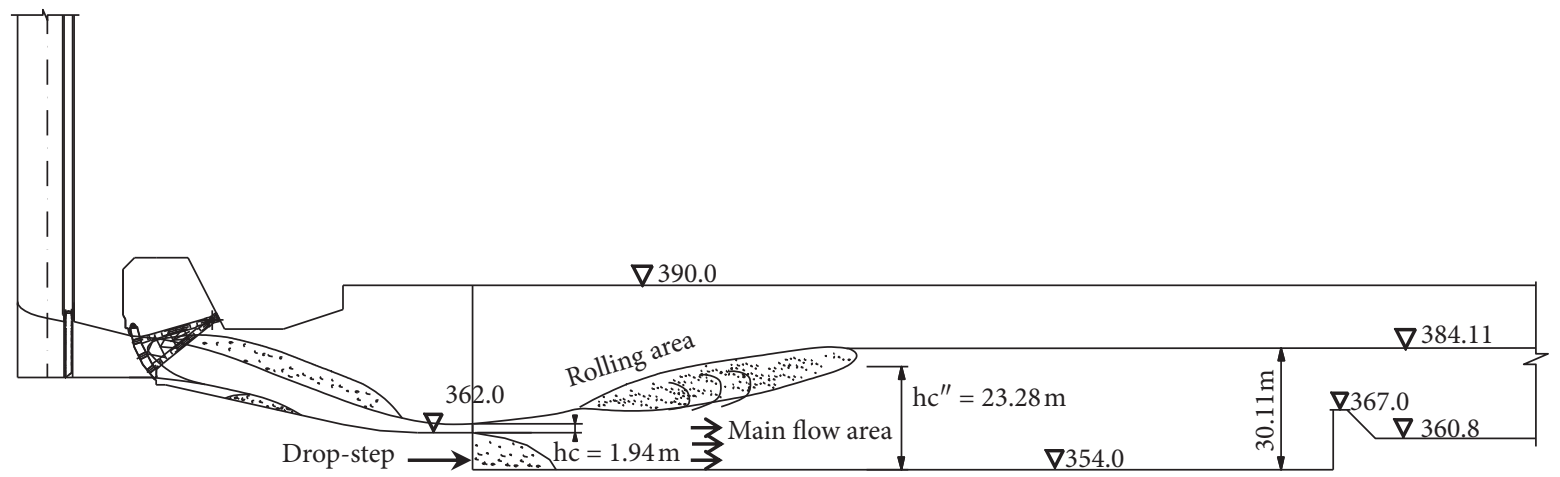

FIgURE 15: Diagram of hydraulic jump (unit: $\mathrm{m}$ ).

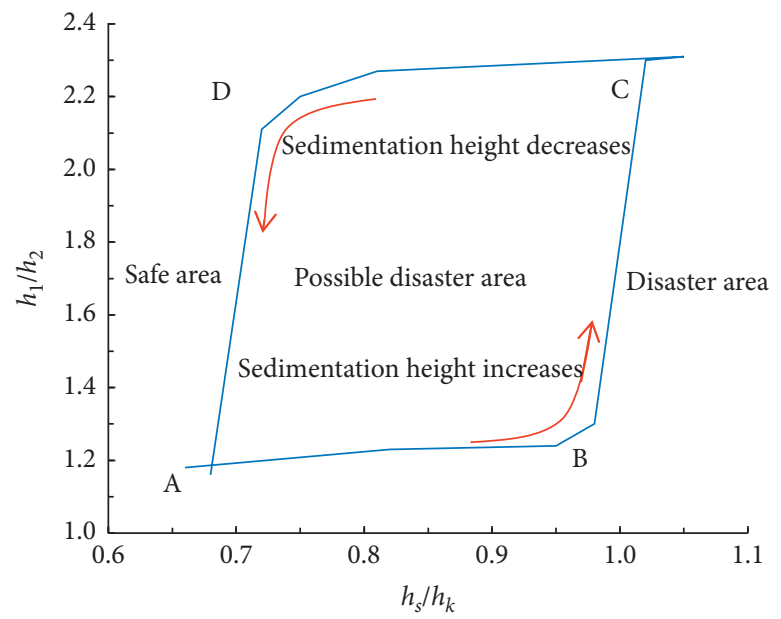

FiguRe 16: Division of disaster areas.

is the slope of apron, $i_{2}$ is the slope at upstream face of the sediment, and $F_{r}$ is the Froude number of the flow.

$$
h_{k}=\sqrt[3]{\frac{\alpha q^{2}}{g}},
$$

where $\alpha$ is the kinetic energy correction factor, usually $\alpha \approx 1$, $q$ is the unit width discharge, and $g=9.8 \mathrm{~m} / \mathrm{s}^{2}$.

According to the data from Tingzikou, when the flood was discharged in July 2018, the maximum flow discharge of the bottom outlet was $5607 \mathrm{~m}^{3} / \mathrm{s}$, and the unit width discharge was $74.76 \mathrm{~m}^{3} / \mathrm{s}$. The critical water depth of the bottom outlet stilling basin was $8.293 \mathrm{~m}$. The calculation process is shown in Table 4.

When $h_{s}<0.418 \mathrm{~m}$, the sediment has no obvious impact on the safety of the stilling basin.

When $0.418 \mathrm{~m} \leq h_{s} \leq 1.246 \mathrm{~m}$, the sediment has great impact on the safety of the stilling basin.

When $h_{s}>1.246 \mathrm{~m}$, the sediment has significant impact on the safety of the stilling basin.

During the formal safety assessment (FSA) of hydraulic structures, the safety status is often divided into five grades including normal, basically normal, mildly abnormal, abnormal, and dangerous, and it is necessary to comprehensively consider the relevant characteristic indicators such as deformation, seepage, and stress [42]. However, in the FSA of stilling basin, monitoring indicators (such as uplift and seepage discharge), measurement indicators (such as sedimentation height and rock mass quality), inspection indicators (such as corrasion and flatness), and numerical simulation indicators (such as velocity, pressure, and turbulent kinetic energy), etc. are often considered. In order to correspond to the grading standards of the overall safety evaluation, the sedimentation height is used as one of the FSA indexes for stilling basin, and it is also recommended to be divided into five grades. Based on the calculations of the upper and lower critical sedimentation heights, and the division of the sedimentation height on the safety of the stilling basin, using the method of equalization interpolation, the sedimentation height classification of the bottom outlet stilling basin is shown in Table 5 .

According to the underwater topographic survey results of bottom outlet stilling basin, the safety grade of sedimentation height of stilling basin floor is evaluated by the methods above. It can be found that the maximum sedimentation height of the apron in bottom outlet stilling basin is $2.04 \mathrm{~m}$, and the average sedimentation height in the sedimentation area is more than $1 \mathrm{~m}$; that means the safety 
TABLE 4: The main calculation parameters of critical sedimentation height of bottom outlet stilling basin.

\begin{tabular}{lc}
\hline Parameters involved in calculation & Value \\
\hline Bottom outlet flow & $5607 \mathrm{~m}^{3} / \mathrm{s}$ \\
Bottom outlet stilling basin width & $75 \mathrm{~m}$ \\
Single-width flow & $74.76 \mathrm{~m}^{3} / \mathrm{s}$ \\
Critical water depth & $8.293 \mathrm{~m}$ \\
$F r$ & 8.83 \\
$i_{1}$ & 0 \\
$i_{2}$ & 0.54 \\
$h_{s 1}$ & $1.246 \mathrm{~m}$ \\
$h_{s 2}$ & $0.418 \mathrm{~m}$ \\
\hline
\end{tabular}

Therefore, the judgment of the impact of the sedimentation height on the safety of the stilling basin is as follows.

TABLE 5: The safety grade classification of sedimentation height of bottom outlet stilling basin.

\begin{tabular}{lccc}
\hline$j$ & Safety grade & Minimum $(\mathrm{m})$ & Maximum $(\mathrm{m})$ \\
\hline 1 & Normal & 0 & 0.209 \\
2 & Basically normal & 0.209 & 0.418 \\
3 & Mildly abnormal & 0.418 & 0.832 \\
4 & Abnormal & 0.832 & 1.246 \\
5 & Dangerous & 1.246 & + \\
\hline
\end{tabular}

grade of sedimentation in this area has reached the abnormal grade dangerous grade, and it is necessary to take engineering measures to clean up the sedimentation. However, in the remaining areas of the bottom outlet stilling basin, the sedimentation height is generally not more than $0.4 \mathrm{~m}$, which belongs to the normal grade basically normal grade. The table above is the safety grade classification of sedimentation height for bottom outlet stilling basin of Tingzikou. As different engineering has different characteristic parameters, which may result in different classification tables, in order to obtain the sedimentation height classification table applicable to different engineering conditions, more engineering cases are needed for further research.

\section{Conclusions}

Based on the combination of GPS-RTK and depth sounder, the unmanned underwater topographic survey system has the advantages of flexibility, high efficiency, safety, high precision, and low cost compared with traditional survey methods. This paper elaborated the system design, standardized operation process, and tree-dimensional model construction method of underwater topographic survey of the typical survey scene of stilling basin and they have been successfully applied to the underwater topographic survey of Tingzikou stilling basin after flood season. The underwater topographic survey of stilling basin is an application innovation of frontier survey technology effectively applied in the field of water conservancy and hydropower engineering, with significant application research value and promotion significance. The main conclusions are as follows:
(1) For the surface outlet stilling basin of Tingzikou, the structures are complete after flood season, the boundaries are clear, and the water quality in it is clear. No apparent sediment or anomalous structure change of stilling basin has been found. Affected by the bedrock and cofferdam cobble and gravel sediment, the elevation of antiscour section and downstream convergence section increased significantly. For the bottom outlet stilling basin of Tingzikou, the sediment within the range of $20 \mathrm{~m} \sim 40 \mathrm{~m}$ away from the bottom sill is large, and the maximum height of it reaches $2.04 \mathrm{~m}$, while there is no obvious sediment or structural abnormality in the remaining region of basin. Affected by the bedrock and cofferdam cobble gravel sediments, the elevation of the antiscour section and the downstream convergence section of the bottom outlet stilling basin increased significantly.

(2) The bottom outlet stilling basin has both the functions of flood discharge and sand discharge. Affected by the backflow, the sediment carrying capacity of the flow is reduced in the process of dissipation and large sediment is formed at a distance of $20 \mathrm{~m} \sim 40 \mathrm{~m}$ from the bottom sill. The height of the sediment has different effects on the safety of stilling basin. Based on the critical sediment height, five safety grades of sedimentation and their division intervals are determined, which provide a reliable support for the overall safety evaluation of the stilling basin.

(3) The surveying and mapping data and 3D model of the unmanned survey system show the elevation trend of the overflow dam section, the apron, the end sill, the antiscour section, and the river convergence section, which can be effectively combined with the building reference value to describe the degree and distribution of underwater sediment. In further research and application, including but not limited to, the side wall effect in inspection route planning and the wave effect should be focused. In order to improve the coverage integrity and accuracy of the survey area, in addition to grasping the ideal survey time, we should explore some technical methods, such as manual mode compensation, hull attitude control, data correction, etc.

\section{Data Availability}

The data used to support the findings of this study are available from the corresponding author upon request.

\section{Conflicts of Interest}

The authors declare that there are no conflicts of interest regarding the publication of this paper.

\section{Acknowledgments}

This work was supported by the National Key R\&D Program of China (Nos. 2019YFB1310505, 2019YFB1310504), Open 
Research Fund Program of State Key Laboratory of Hydroscience and Engineering (sklhse-2019-B-06), and Sichuan Science and Technology Program (Nos. 2021YFG0100, 2020JDRC0130, 2019YFG0143).

\section{References}

[1] T. Honar, N. Khoramshokooh, and M. R. Nikoo, "Hydraulic optimization of corrugated stilling basin with adverse slope," Water Supply, vol. 19, no. 1, pp. 313-322, 2019.

[2] J. Guo and J. Z. Gao, "Discussions on operation safety of discharge facilities with high head and large discharge flow," Journal of Hydroelectric Engineering, vol. 32, no. 5, pp. 169173, 2013, in Chinese.

[3] L. J. Wang, H. F. Qin, and T. Li, "Experimental study on hydraulic characteristics of stilling pool with contraction pier and falling sill," Water Resources and Hydropower Engineering, vol. 47, no. 10, pp. 40-44, 2016, in Chinese.

[4] L. M. Limantara, D. Priyantoro, and L. Prasetyorini, "Design of stilling basin for decreasing back water in the dam foot," International Journal of Geomate, vol. 15, no. 51, pp. 98-105, 2018.

[5] F. Naseri, H. Sarkardeh, and E. Jabbari, "Effect of inlet flow condition on hydrodynamic parameters of stilling basins," ACTA Mechanica, vol. 229, no. 3, pp. 1415-1428, 2018.

[6] Z. Zhou and J. X. Wang, "Hydraulic study of combined stilling basin between overflowing orifice and bottom outlet in Lianhuasi Hydropower Station," Engineering Journal of Wuhan University, vol. 52, no. 3, pp. 201-206, 2019, in Chinese.

[7] A. M. Hayder, "A laboratory study on stilling basin with semicircular rough bed elements," Jordan Journal of Civil Engineering, vol. 11, no. 2, pp. 198-205, 2017.

[8] T. X. Chen, R. H. Wei, and J. Zhang, "Application of the 5th generation multi-beam depth-sounding system in reservoir storage survey," Yangtze River, vol. 47, no. 9, pp. 29-32, 2016, in Chinese.

[9] R.-J. Yan, S. Pang, H.-B. Sun, and Y.-J. Pang, "Development and missions of unmanned surface vehicle," Journal of Marine Science and Application, vol. 9, no. 4, pp. 451-457, 2010.

[10] R. B. Rubén, A. G. Miguel, and E. Cecilia, "Experimental evaluation of an autonomous surface craft for shallow-water bathymetry," Marine Technology Society Journal, vol. 51, no. 4, pp. 59-67, 2017.

[11] X. Y. Liu and X. P. Mao, "Application of multi-beam sounding system in review of reservoir capacity and sediment," Dam and Safety, vol. 6, pp. 24-26, 2013, in Chinese.

[12] Y. Li, X. Li, H. Wang, S. Wang, S. Gu, and H. Zhang, "Exposed aggregate detection of stilling basin slabs using attention U-net network," KSCE Journal of Civil Engineering, vol. 24, p. 17406, 2020.

[13] I. M. Konstantin, I. P. Nicholaus, and W. M. Alexander, "Development of a remotely controlled testing platform with low-drag air-ventilated hull," Journal of Marine Science and Application, vol. 14, no. 1, pp. 25-29, 2015.

[14] J. M. Peschel and R. R. Murphy, "On the human-machine interaction of unmanned aerial system mission specialists," IEEE Transactions on Human-Machine Systems, vol. 43, no. 1, pp. 53-62, 2013.

[15] Z. B. Gao, X. J. Li, and P. An, "Application of GPS-RTK cooperating with depth sounder in river cross section measurement," Yellow River, vol. 33, no. 12, pp. 24-26, 2011, in Chinese.
[16] C. Zhang, N. X. Mou, and X. Zhou, "Application of unmanned intelligent technology in topographic surveying and capacity calculation of reservoir," Bulletin of Surveying and Mapping, vol. 11, pp. 72-76, 2017.

[17] H. Yang, J. B. Xu, and H. Huang, "Underwater terrain surveying and mapping of daning reservoir by unmanned boat surveying and mapping system," Beijing Surveying and Mapping, vol. S2, pp. 51-54, 2017, in Chinese.

[18] A. Ajith, R. Rajkumar, and R. M. Shibu, "Design and development of novel system for increasing range of an unmanned underwater vehicle," in Proceedings of the 2019 IEEE Underwater Technology (UT), Kaohsiung, China, April 2019.

[19] Z. Y. Liang, "Application of unmanned surface vehicle surveying system in reservoir topographic survey," Urban Geotechnical Investigation and Surveying, vol. 1, pp. 132-135, 2018, in Chinese.

[20] Y. F. Cao and H. Gao, "Application of ship-borne mobile mapping system in acquiring reservoir topography information," Geomatics and Spatial Information Technology, vol. 41, no. 3, pp. 57-64, 2018, in Chinese.

[21] J. C. Jin, J. Zhang, and Y. Ma, "An unmanned surface vehicle for bathymetry," Hydrographic Surveying and Charting, vol. 33, no. 2, pp. 53-56, 2013, in Chinese.

[22] C. Powers, R. Hanlon, and D. G. Schmale, "Remote collection of microorganisms at two depths in a freshwater lake using an unmanned surface vehicle (USV)," Peer Journal, vol. 6, no. 5, pp. 1-16, 2018.

[23] B. R. Dzikowicz, B. T. Hefner, and R. A. Leasko, "Underwater acoustic navigation using a beacon with a spiral wave front," IEEE Journal of Oceanic Engineering, vol. 40, no. 1, pp. 177186, 2015.

[24] D. P. Eickstedt, M. R. Benjamin, and H. Schmidt, "Adaptive control of heterogeneous marine sensor platforms in an autonomous sensor network," in Proceedings of the International Conference on Intelligent Robots and Systems, pp. 5514-5521, IEEE, Beijing, China, October 2016.

[25] J. C. Jin, J. Zhang, and F. Shao, "An unmanned surface vehicle for ocean environment monitoring and its oceanic application," Coastal Engineering, vol. 34, no. 3, pp. 87-92, 2015, in Chinese.

[26] Y. Sierra, P. Joshua, and P. Gopal, "Robot-assisted measurement for hydrologic understanding in data sparse regions," Water, vol. 9, no. 7, p. 494, 2017.

[27] Y. Z. Wang and Y. Z. Zhang, "Numerical simulation of distribution of sediment deposition on the joints in canal systems," Journal of Irrigation and Drainage, vol. 37, no. 5, pp. 81-85, 2018.

[28] M. Athat, U. C. Kothyari, and R. J. Garde, "Distribution of sediment concentration in the vortex chamber type sediment extractor," Journal of Hydrological Research, vol. 41, no. 4, pp. 427-438, 2003.

[29] Z. P. Zhao, X. S. Xie, and K. F. Lin, "Numerical simulation of characteristics of flow field and sediment movement," Yellow River, vol. 40, no. 2, pp. 105-134, 2018.

[30] M. A. Madej, D. G. Sutherland, T. E. Lisle, and B. Pryor, "Channel responses to varying sediment input: a flume experiment modeled after Redwood Creek, California," Geomorphology, vol. 103, no. 4, pp. 507-519, 2009.

[31] X. K. Wang, M. Asim, and L. Wang, "Experimental study on sediment deposition in circulation zone of shallow water flows," Journal of Hydroelectric Engineering, vol. 28, no. 4, pp. 149-153, 2009. 
[32] C. L. Zhang, J. C. Guan, and C. M. Fang, "Experimental study on the response of river to water and sediment supply processes," Journal of Sediment Research, vol. 2, pp. 15-20, 2018.

[33] T. Song, Y. M. Chiew, and C. O. Chin, "Effect of bed-load movement on flow friction factor," Journal of Hydraulic Engineering, vol. 124, no. 2, pp. 165-175, 1998.

[34] P. Gao and A. D. Abrahams, "Bedload transport resistance in rough open-channel flows," Earth Surface Processes and Landforms, vol. 29, no. 4, pp. 423-435, 2004.

[35] Q. Y. Wang, C. H. Lei, and L. H. Zeng, "Design of Tingzikou water control project," Water Power, vol. 35, no. 10, pp. 26-28, 2009, in Chinese.

[36] H. R. Wang, S. Wang, and Y. C. Chen, "Application of unmanned intelligent technologies in underwater topographic survey of stilling basins," Journal of Hydroelectric Engineering, vol. 38, no. 12, pp. 11-18, 2019, in Chinese.

[37] Y. Li, H. Zhang, S. Wang, H. Wang, and J. Li, "Image-based underwater inspection system for abrasion of stilling basin slabs of dam," Advances in Civil Engineering, vol. 2019, pp. 1-13, Article ID 6924976, 2019.

[38] L. H. Zhu and Q. Hu, "The Application of GPS-RTK and bathymetric technologies in underwater topographic survey," Geomatics and Spatial Information Technology, vol. 34, no. 5, pp. 162-164, 2011, in Chinese.

[39] Y. H. Yan, J. X. Xu, and W. Q. Wu, "Application of GPS-PPK connecting depth sounder in underwater topographic survey," Yellow River, vol. 35, no. 5, pp. 128-130, 2013, in Chinese.

[40] J. Yang, Y. Y. Zhang, and J. C. Feng, "Sediment carrying capacity downstream of the spur dike in open channel flow," Journal of MUC (National Sciences Edition), vol. 25, no. 2, pp. 53-57, 2016, in Chinese.

[41] Y. H. Zhong, X. D. Ma, and R. H. Nie, "Experimental study on the effect of siltation height on water level chang in steep slope channel," Advanced Engineering Sciences, vol. 51, no. 6, pp. 134-138, 2019, in Chinese.

[42] Z. R. Wu, C. S. Gu, and D. J. Zheng, "Theory and method on life diagnosis in important hydraulic engineerings," Chinese Journal of Rock Mechanics and Engineering, vol. 24, no. 17, pp. 3017-3022, 2005, in Chinese. 